\title{
A new species of Ampharete (Annelida: Ampharetidae) from the West Shetland shelf (NE Atlantic Ocean), with two updated keys to the species of the genus in North Atlantic waters
}

\author{
Julio PARAPAR ${ }^{1, *}$, Juan MOREIRA $^{2}$ \& Ruth BARNICH ${ }^{3}$ \\ ${ }^{1}$ Departamento de Bioloxía, Universidade da Coruña, Rúa da Fraga 10, \\ 15008 A Coruña, Galicia, Spain. \\ ${ }^{2}$ Departamento de Biología (Zoología), Facultad de Ciencias, \\ Universidad Autónoma de Madrid, 28049 Madrid, Spain. \\ ${ }^{2}$ Centro de Investigación en Biodiversidad y Cambio Global (CIBC-UAM), \\ Universidad Autónoma de Madrid, 28049 Madrid, Spain. \\ ${ }^{3}$ Thomson Unicomarine Ltd., Compass House, Surrey Research Park, \\ Guildford, GU2 7AG, United Kingdom. \\ *Corresponding author: julio.parapar@udc.es \\ 2Email:juan.moreira@uam.es \\ ${ }^{3}$ Email: ruth.barnich@thomsonec.com \\ ${ }^{1}$ urn:lsid:zoobank.org:author:CE188F30-C9B0-44B1-8098-402D2A2F9BA5 \\ ${ }^{2}$ urn:1sid:zoobank.org:author:B1E38B9B-7751-46E0-BEFD-7C77F7BBBEF0 \\ ${ }^{3}$ urn:lsid:zoobank.org:author:F1E3AEB7-0C77-41BB-8A6C-F8B429F17DA1
}

\begin{abstract}
Ampharete oculicirrata sp. nov. (Annelida: Ampharetidae) is described from samples collected by the Joint Nature Conservation Committee and Marine Scotland Science, in the West Shetland Shelf NCMPA in the NE Atlantic. This species is characterised by a very small body size, thin and slender paleae, twelve thoracic and eleven abdominal uncinigers, presence of eyes both in the prostomium and the pygidium, the latter provided with a pair of long lateral cirri. The external micro-morphology of the new taxon was studied using scanning electron microscopy and compared with species described or reported from the North Atlantic. Two complementary keys to all species of Ampharete in the area are also provided.
\end{abstract}

Keywords. Taxonomy, new species, West Shetland shelf, SEM, identification key.

Parapar J., Moreira J. \& Barnich R. 2019. A new species of Ampharete (Annelida: Ampharetidae) from the West Shetland shelf (NE Atlantic Ocean), with two updated keys to the species of the genus in North Atlantic waters. European Journal of Taxonomy 531: 1-16. https://doi.org/10.5852/ejt.2019.531

\section{Introduction}

The genus Ampharete Malmgren, 1866, as defined by Jirkov (2011), is a species-rich genus of sedimentdwelling polychaetes comprising about 40 nominal species worldwide (Parapar et al. 2012). The 
traditional generic diagnosis of Ampharete (e.g., Holthe 1986) has been emended by Jirkov (1994, 2001, 2011) and then followed by a number of authors (e.g., Imajima et al. 2012; Parapar et al. 2012, 2018; Alvestad et al. 2014). Consequently, other genera have been considered as synonyms of Ampharete: Asabellides Annenkova, 1929; Parampharete Hartman, 1978; Pterampharete Augener, 1918; and Sabellides Milne-Edwards in Lamarck, 1838. Following Imajima et al. (2012), species of Ampharete mostly share characters such as buccal tentacles with secondary filaments (pinnae); a prostomium lacking glandular ridges, but provided with a middle lobe delimited by a more or less defined U-shaped incision; four pairs of branchiae disposed along a transverse line in the fused segments II+III, with the fourth pair slightly displaced posteriorly; a pair of nephridial papillae located middorsally behind branchiae; two intermediate uncinigers (AU1, AU2); absence of modified noto and neuropodia; and usually little developed glandular pads in intermediate and abdominal uncinigers.

The North Atlantic species of Ampharete have been studied by Holthe (1986), Jirkov (1997, 2001), Parapar et al. (2012, 2018), and Alvestad et al. (2014) among others. However, there are still many geographic and bathymetric gaps in our knowledge of this genus; for instance, the West Atlantic coast and deep-sea habitats have been comparatively less studied. Furthermore, as demonstrated recently for the trichobranchid genus Terebellides Sars, 1835 by Nygren et al. (2018), there is most likely also a hidden diversity within the species complex Ampharete lindstroemi Malmgren in Hessle, 1917.

The present study is based on specimens collected from the West Shetland shelf obtained during a survey undertaken by the Joint Nature Conservation Committee (JNCC) and Marine Scotland Science (MSS). In the course of a biodiversity assessment carried out by Thomson Unicomarine Ltd. numerous specimens of a small-sized undescribed species of Ampharete were found by one of us (RB) and described herein as Ampharete oculicirrata sp. nov. Furthermore, two updated complimentary keys to all species of the genus Ampharete in North Atlantic waters based on Parapar et al. (2012) are provided.

\section{Materials and methods}

This study is based on material collected in the West Shetland Shelf Nature Conservation Marine Protected Area (NCMPA) by JNCC and MSS on MRV Scotia and analysed by Thomson Unicomarine Ltd (Taylor et al. in press). This Marine Protected Area is characterised by sand and gravel habitats and the depth ranges from 100 to $140 \mathrm{~m}$. It is located north of mainland Scotland, west of the Orkneys and close to the Wyville Thomson Ridge.

Observations, drawings and measurements of specimens were made using an Olympus BX51 compound microscope provided with a camera lucida. Specimens were stained with methylene blue for light microscopy examination of body and parapodia. Specimens selected for Scanning Electron Microscopy (SEM) examination were dehydrated in a graded ethanol series, critical-point dried using $\mathrm{CO}_{2}$, mounted on aluminium stubs, covered with gold in a BAL-TEC SCD 004 evaporator, and examined and photographed under a JEOL JSM-6400 scanning electron microscope at the Servizos de Apoio á Investigación, Universidade da Coruña (SAI-UDC), Spain.

In total 85 specimens and one posterior end were collected in 21 stations from the West Shetland Shelf NCMPA. Of these, 82 were selected as type specimens and are deposited in the National Museum of Scotland (NMS; holotype and 47 paratypes), the Museo Nacional de Ciencias Naturales (MNCN, Madrid; 29 paratypes), and the Senckenberg Museum (SMF, Frankfurt; 5 paratypes). Some additional non-type specimens are deposited in the collections of Marine Scotland Science and Thomson Unicomarine Ltd. For further details see Table 1. 
Table 1. Type material and sampling localities of Ampharete oculicirrata sp. nov. Paratypes marked with (*) are females with eggs and with (**) are mounted on SEM stubs.

\begin{tabular}{|c|c|c|c|c|c|c|}
\hline $\begin{array}{c}\text { Collection \& reg. } \\
\text { number }\end{array}$ & $\begin{array}{c}\text { Number of } \\
\text { spec. \& status }\end{array}$ & Station number & $\begin{array}{c}\text { Depth } \\
\text { (m) }\end{array}$ & $\begin{array}{c}\text { Date } \\
\text { sampled }\end{array}$ & $\begin{array}{l}\text { Latitude } \\
\qquad \mathbf{N}\end{array}$ & $\begin{array}{c}\text { Longitude } \\
\text { W }\end{array}$ \\
\hline NMS.Z.2019.8.1 & holotype & 1517S WSS 13 S103 & 130 & 2 Nov. 2017 & $59.40^{\circ}$ & $5.92^{\circ}$ \\
\hline NMS.Z.2019.8.2 & 1 paratype & 1517S WSS 06 S97 & 130 & 2 Nov. 2017 & $59.41^{\circ}$ & $5.98^{\circ}$ \\
\hline NMS.Z.2019.8.3 & 10 paratypes & 1517S WSS 24 S119 & 126 & 3 Nov. 2017 & $59.49^{\circ}$ & $5.81^{\circ}$ \\
\hline NMS.Z.2019.8.4 & 3 paratypes & 1517S WSS 25 S112 & 125 & 2 Nov. 2017 & $59.38^{\circ}$ & $5.80^{\circ}$ \\
\hline NMS.Z.2019.8.5 & 2 paratypes & 1517S WSS 29 S113 & 124 & 2 Nov. 2017 & $59.35^{\circ}$ & $5.77^{\circ}$ \\
\hline NMS.Z.2019.8.6 & 8 paratypes & 1517S WSS 30 S115 & 123 & 2 Nov. 2017 & $59.40^{\circ}$ & $5.77^{\circ}$ \\
\hline NMS.Z.2019.8.7 & 9 paratypes & $1517 \mathrm{~S}$ & 121 & 3 Nov. 2017 & $59.49^{\circ}$ & $5.71^{\circ}$ \\
\hline NMS.Z.2019.8.8 & 4 paratypes & 1517S WSS 43 S130 & 114 & 3 Nov. 2017 & $59.33^{\circ}$ & $5.70^{\circ}$ \\
\hline NMS.Z.2019.8.9 & 6 paratypes & 1517S WSS 44 S128 & 120 & 3 Nov. 2017 & $59.38^{\circ}$ & $5.69^{\circ}$ \\
\hline NMS.Z.2019.8.10 & 4 paratypes & 1517S WSS 45 S126 & 120 & 3 Nov. 2017 & $59.42^{\circ}$ & $5.69^{\circ}$ \\
\hline MNCN 16.01/18474 & 2 paratypes & 1517S WSS 17 S106 & 138 & 2 Nov. 2017 & $59.50^{\circ}$ & $5.92^{\circ}$ \\
\hline MNCN 16.01/18475 & 1 paratype* & 1517S WSS 17 S106 & 138 & 2 Nov. 2017 & $59.50^{\circ}$ & $5.92^{\circ}$ \\
\hline MNCN 16.01/18476 & 2 paratypes & 1517S WSS 35 S116 & 121 & 2 Nov. 2017 & $59.42^{\circ}$ & $5.74^{\circ}$ \\
\hline MNCN 16.01/18477 & 7 paratypes & $1517 \mathrm{~S}$ WSS $31 \mathrm{~S} 117$ & 125 & 2 Nov. 2017 & $59.45^{\circ}$ & $5.77^{\circ}$ \\
\hline MNCN 16.01/18478 & 6 paratypes & $1517 \mathrm{~S}$ WSS $50 \mathrm{~S} 136$ & 119 & 3 Nov. 2017 & $59.44^{\circ}$ & $5.66^{\circ}$ \\
\hline MNCN 16.01/18479 & 4 paratypes & $1517 \mathrm{~S}$ WSS 46 S137 & 123 & 3 Nov. 2017 & $59.47^{\circ}$ & $5.68^{\circ}$ \\
\hline MNCN 16.01/18480 & 1 paratype & 1517S WSS 57 S145 & 113 & 3 Nov. 2017 & $59.42^{\circ}$ & $5.64^{\circ}$ \\
\hline MNCN 16.01/18481 & 1 paratype* & 1517S WSS 72 S156 & 114 & 4 Nov. 2017 & $59.44^{\circ}$ & $5.55^{\circ}$ \\
\hline MNCN 16.01/18482 & 5 paratypes $* *$ & 1517S WSS 72 S156 & 114 & 4 Nov. 2017 & $59.44^{\circ}$ & $5.55^{\circ}$ \\
\hline SMF 25324 & 4 paratypes & 1517S WSS 47 S139 & 114 & 3 Nov. 2017 & $59.52^{\circ}$ & $5.68^{\circ}$ \\
\hline SMF 25325 & 1 paratype & 1517S WSS 55 S135 & 118 & 3 Nov. 2017 & $59.42^{\circ}$ & $5.64^{\circ}$ \\
\hline TUM 66706 & 3 non-types & 1517S WSS 01 S95 & 130 & 2 Nov. 2017 & $59.38^{\circ}$ & $6.06^{\circ}$ \\
\hline JNCC 66716 & 1 non-type & 1517S WSS 15 S102 & 131 & 2 Nov. 2017 & $59.38^{\circ}$ & $5.90^{\circ}$ \\
\hline
\end{tabular}

\section{List of abbreviations}

$\begin{array}{ll}\mathrm{AU} & =\text { abdominal unciniger } \\ \mathrm{bl} & =\text { buccal lip } \\ \mathrm{br} & =\text { branchia } \\ \mathrm{brph} & =\text { branchiophore } \\ \mathrm{bt} & =\text { buccal tentacle } \\ \mathrm{btp} & =\text { buccal tentacle pinna } \\ \text { eye }(\mathrm{i}) & =\text { pygidial eye } \\ \text { eye }(\mathrm{p}) & =\text { prostomial eye } \\ \text { nuo } & =\text { nuchal organ } \\ \text { pal } & =\text { paleae } \\ \text { plc } & =\text { pygidial lateral cirrus } \\ \mathrm{pp} & =\text { pygidial papillae }\end{array}$




$$
\begin{array}{lll}
\operatorname{pros}(11) & = & \text { prostomium (lateral lobe) } \\
\operatorname{pros}(\mathrm{ml}) & = & \text { prostomium (median lobe) } \\
\mathrm{SG} & = & \text { segment } \\
\mathrm{TN} & = & \text { thoracic notopodium } \\
\mathrm{TU} & = & \text { thoracic unciniger } \\
\mathrm{vS} & = & \text { ventral shield } \\
\mathrm{vpo} & = & \text { ventral pharyngeal organ }
\end{array}
$$

\section{Results}

Phylum Annelida Lamarck, 1809

Family Ampharetidae Malmgren, 1866

Genus Ampharete Malmgren, 1866

Ampharete oculicirrata sp. nov.

urn:1sid:zoobank.org:act:BE4BEBF8-5E0B-4E75-9B7E-1EA9380B199B

Figs 1-7; Table 1

\section{Diagnosis}

Measurements. Small-sized species of up to $10 \mathrm{~mm}$ in length and $1.0 \mathrm{~mm}$ in width.

Prostomium AND PYgIDIUM. Provided each with a pair of dark eyes.

BRANCHIAE. Arranged in two groups separated by a short gap.

Paleae. Thin and slender with filiform tips, 5-7 on each side; slightly longer and wider than regular thoracic notochaetae.

THORAX AND ABDOMEN. Twelve thoracic uncinigers and 11 abdominal uncinigers without dorsal neuropodial cirrus (first two of thoracic shape).

Pygidium. Lobulated with two long lateral cirri.

\section{Etymology}

The epithet oculicirrata from the Latin 'oculi', meaning 'eyes', and 'cirrata', meaning 'in cirrus' refers to the conspicuously pigmented eyespots laterally on the long pygidial cirri.

\section{Material examined}

\section{Holotype}

SCOTLAND - holotype; West Shetland shelf, west of the Orkneys; station number 1517S WSS 13 S103; 59.40 N, 5.92 ${ }^{\circ}$ W; 130 m depth; 2 Nov. 2017; EtOH preserved; NMS.Z.2019.8.1.

\section{Paratypes}

SCOTLAND - Eighty-one specimens; same area as for holotype but from different sampling localities; either preserved in EtOH, in the same way as the holotype, or prepared for SEM (MNCN 16.01/18482) - 2 q+ with oocytes; collection data of each sampling station and museum registration numbers for each group of paratypes are detailed in Table 1; MNCN 16.01/18475, MNCN 16.01/18481.

Description of holotype (SEM images from paratypes MNCN 16.01/18482)

MeAsurements. Complete specimen of $7.5 \mathrm{~mm}$ length and $0.5 \mathrm{~mm}$ width in thorax. 
Prostomium. Trilobed; rather narrow and protruding median lobe delimited by deep lateral grooves; a pair of nuchal organs as circular ciliated spots located at the base of the median prostomial lobe; prostomial glandular ridges absent (Figs 1C, 2A, 4A-B).

EYES. Two small black, circular eyespots located posteriorly on median prostomial lobe next to the lateral grooves (Fig. 1A, C).
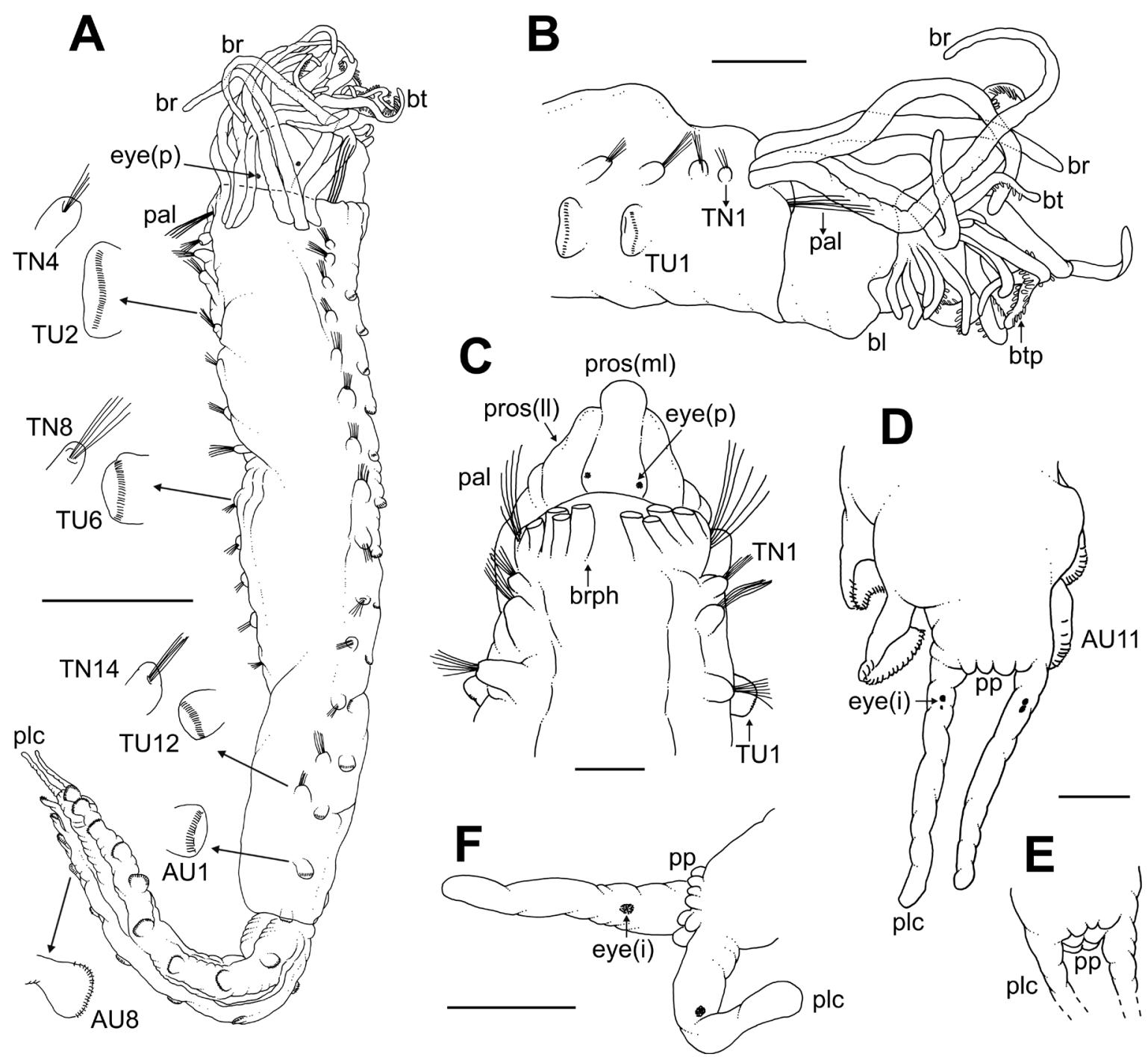

Fig. 1. Ampharete oculicirrata sp. nov., holotype NMS.Z.2019.8.1 (A-B, D-E), paratype MNCN 16.01/18476 (C, F). A. Complete specimen, dorsolateral view, and detail of several thoracic and abdominal parapodia. B. Anterior end, lateral view. C. Anterior end, dorsal view. D-E. Posterior end, dorsal and ventral view. F. Posterior end, lateral view. Abbreviations: $A U=$ abdominal unciniger; $\mathrm{bl}=$ buccal lip; $\mathrm{br}=$ branchia $;$ brph = branchiophore; $\mathrm{bt}=$ buccal tentacle; $\mathrm{btp}=$ buccal tentacle pinna; eye $(\mathrm{i})=$ pygidial eye $;$ eye $(\mathrm{p})=$ prostomial eye $; \mathrm{pal}=$ paleae $; \mathrm{plc}=$ pygidial lateral cirrus $; \mathrm{pp}=$ pygidial papillae; $\operatorname{pros}(11)=\operatorname{prostomium~}($ lateral lobe) $\operatorname{pros}(\mathrm{ml})=$ prostomium $($ median lobe) $\mathrm{TN}=$ thoracic notopodium; TU $=$ thoracic unciniger. Scale bars: $A=1 \mathrm{~mm} ; \mathrm{B}-\mathrm{C}=200 \mu \mathrm{m} ; \mathrm{D}-\mathrm{F}=100 \mu \mathrm{m}$. 
Peristomium. Forming a well-developed buccal lip (Figs 1B, 5B, 7A).

BuCCAL TENTACLES. Without groove, with two ventrolateral rows of long and slender pinnae (longer than tentacle diameter); tips of pinnae covered by cilia (Fig. 7B).

BranchiaE. Four pairs located in fused segments II+III and arranged in two groups with a short median gap, about one branchia wide (Figs 1A, C, 4B); branchiophores fused at base (Figs 1C, 2A-B); branchiae of same width throughout, but slightly tapering at distal end, about 3 times as long as the prostomium and $3 / 5$ as long as the thorax (Figs 1A, 4A-B), reaching about TC6 and provided with parallel ciliated rings from base to distal end (Fig. 4B). Anterior three pairs of branchiae arranged in transverse row, fourth pair posterior to anterior row, between second outermost and innermost branchiae (Fig. 1A, C). Fused segments II+III (SG2+3) provided with 5-6 long, thin and slender chaetae (paleae), slightly longer than following regular notochaetae (Figs 1A-C, 2A-B, 4A-B).

THORAX. Longer and wider than abdomen (Fig. 1A). Fourteen thoracic segments with notopodia and capillary chaetae (SG4 to SG17); last 12 segments also with neuropodial tori bearing single row of
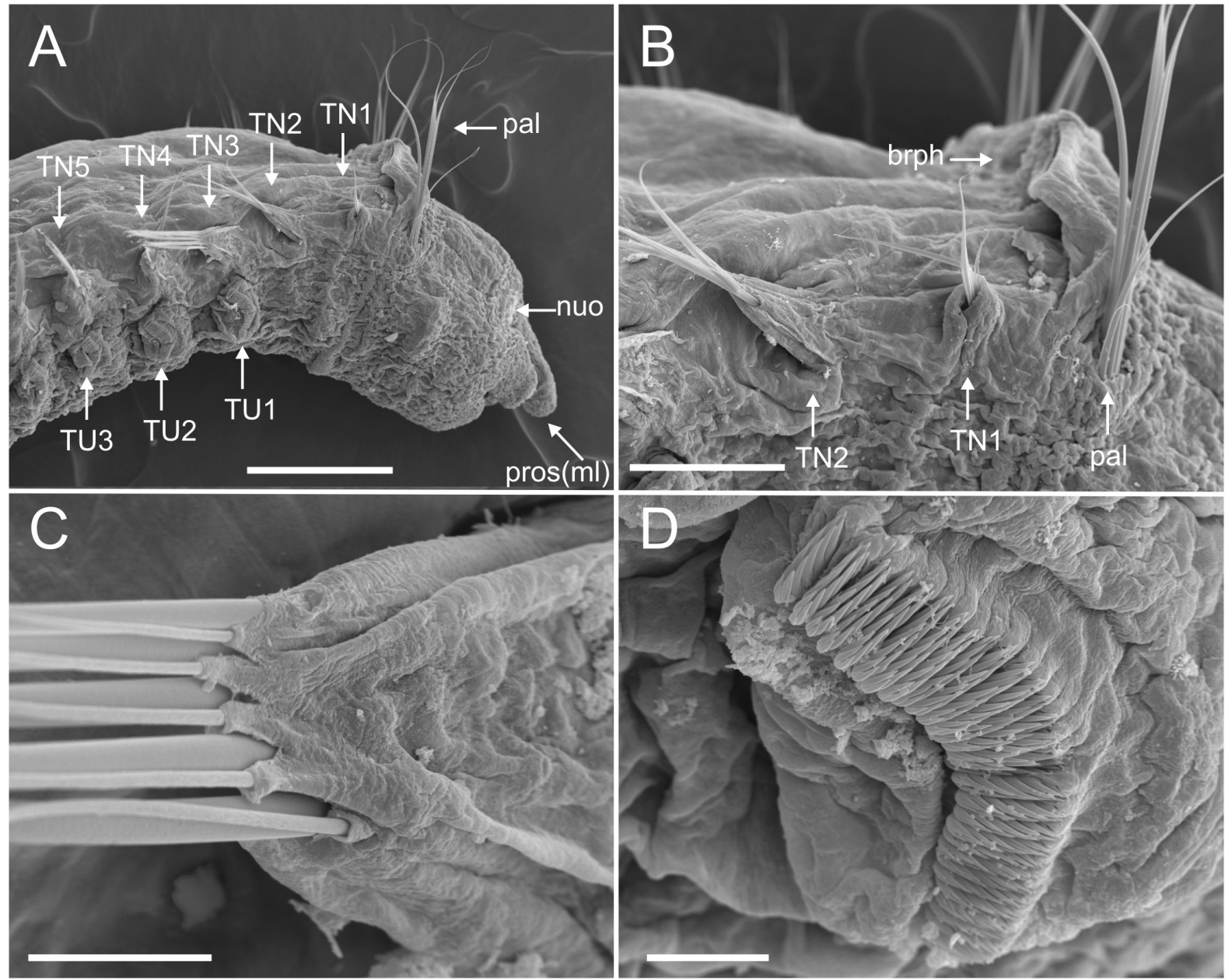

Fig. 2. Ampharete oculicirrata sp. nov., paratype MNCN 16.01/18482_spec. 1. A. Anterior end, lateral view. B. Paleae and first two thoracic chaetigers, lateral view. C. Thoracic notopodium and chaetae, anterior view. D. Uncini of second thoracic unciniger (thoracic chaetiger 4). Abbreviations: brph = branchiophore; nuo = nuchal organ; $\mathrm{pal}=$ paleae; $\operatorname{pros}(\mathrm{ml})=$ prostomium $($ median lobe); $\mathrm{TN}=$ thoracic notopodium; $\mathrm{TU}=$ thoracic unciniger. Scale bars: $\mathrm{A}=200 \mu \mathrm{m} ; \mathrm{B}=100 \mu \mathrm{m} ; \mathrm{C}=20 \mu \mathrm{m} ; \mathrm{D}=15 \mu \mathrm{m}$. 

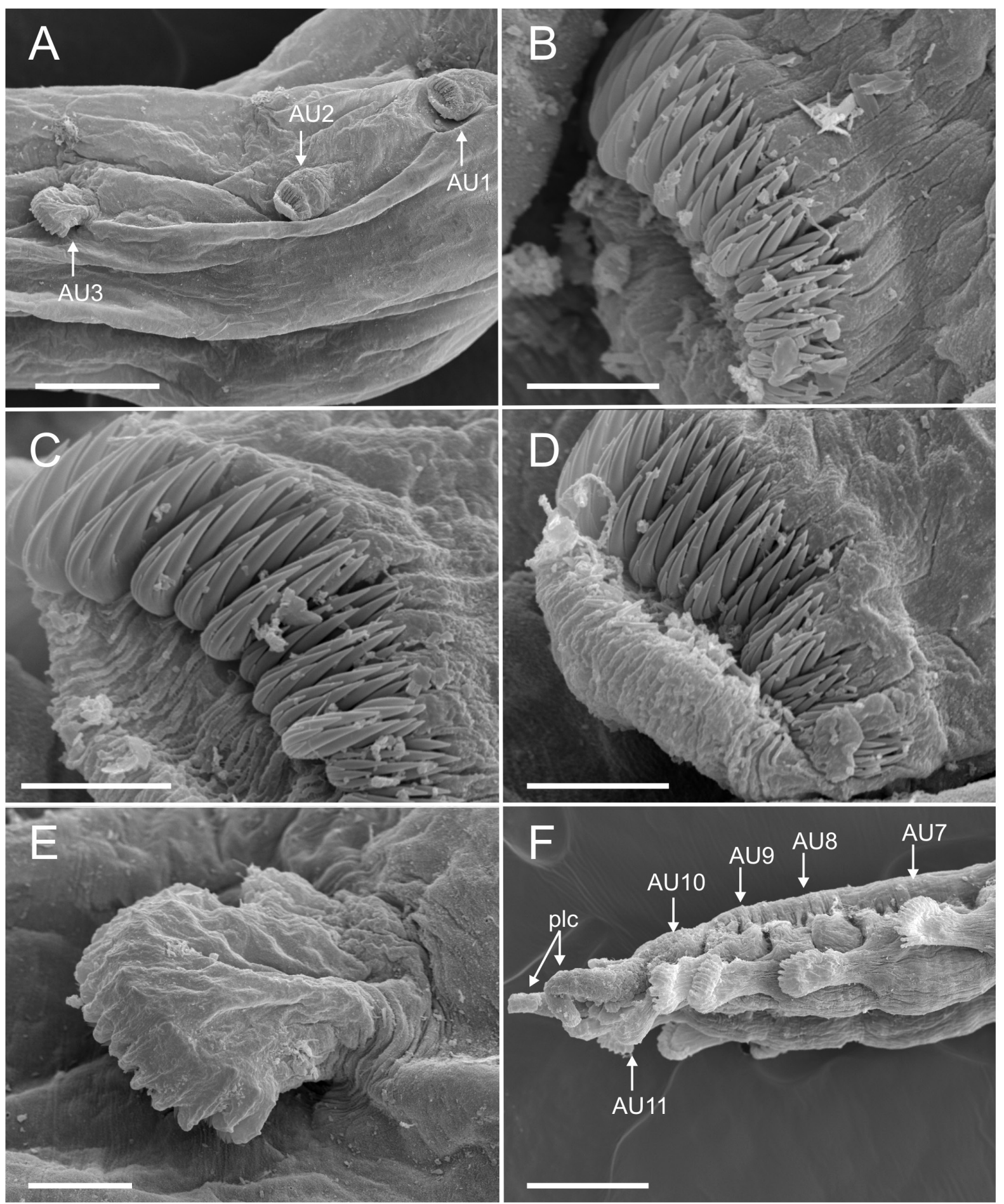

Fig. 3. Ampharete oculicirrata sp. nov., paratype MNCN 16.01/18482_spec. 1. A. First three abdominal uncinigers, lateral view. B. Thoracic unciniger 11. C. Abdominal unciniger 1. D. Abdominal unciniger 2. E. Abdominal unciniger 3. F. Posterior end, from AU7 to pygidium. Abbreviations: $A U=$ abdominal unciniger; plc $=$ pygidial lateral cirrus. Scale bars: A, F $=100 \mu \mathrm{m} ; \mathrm{B}-\mathrm{D}=10 \mu \mathrm{m} ; \mathrm{E}=15 \mu \mathrm{m}$. 
uncini. Nephridial papillae not observed. Thoracic notopodia as simple lobes from SG4 and up to three times longer than wide; first notopodium somewhat reduced (Figs 1A-C, 2A-B). Notochaetae as simple spinulose capillaries, tapering to slender tips; arranged in two rows, capillaries from anterior row much thinner and shorter than those of posterior row (Fig. 2C). Thoracic neuropodia from SG6; anterior ones usually oval-shaped, about three times higher than wide (Figs 1B, 2A, D); gradually decreasing in size, becoming more rounded in posterior part of thorax (Fig. 3B). Cirri and papillae in thoracic parapodia absent. Thoracic uncini with about ten teeth in two vertical rows above rostrum (Fig. 2D). Well-developed ventral shields present to TU10, weakly developed in TU11 and absent in TU12 (Fig. 5A). Elevated or modified notopodia absent.

ABDomEN. Shorter and thinner than thorax. Eleven uncinigers, anterior two (AU1-2) with neuropodia of thoracic type ('intermediate uncinigers') (Figs 1A, 3C-D, 5A); remaining nine abdominal uncinigers (AU3-11) with enlarged neuropodial 'pinnules', without dorsal neuropodial cirrus (Figs 1A, 3E, F,

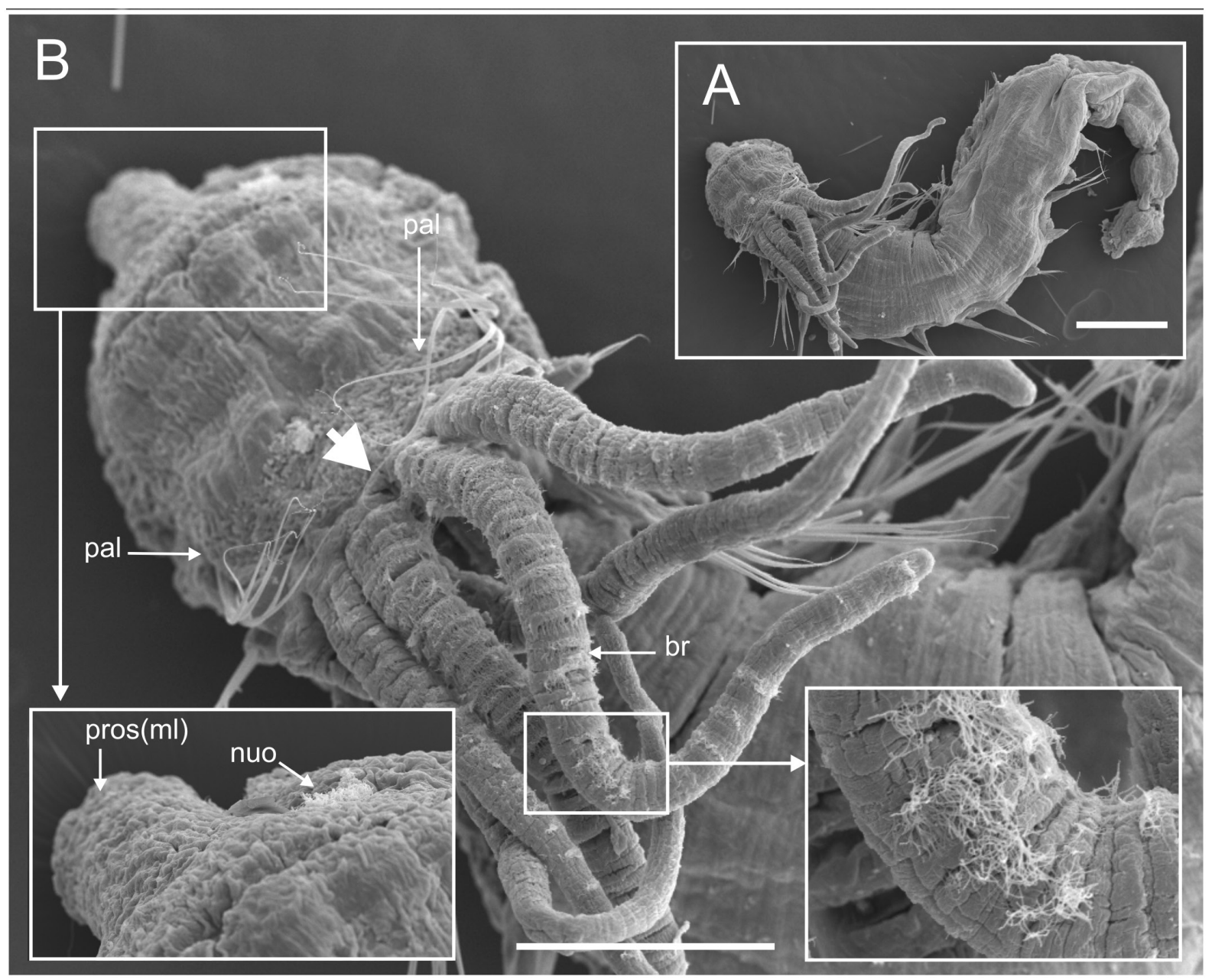

Fig. 4. Ampharete oculicirrata sp. nov., paratype MNCN 16.01/18482_spec. 2. A. Incomplete specimen, dorsal view. B. Anterior end, dorsal view and detail of prostomium and nuchal organ; large arrow pointing to gap between groups of branchiae; framed enlarged areas: prostomium (bottom left) and branchial ciliation (bottom right). Abbreviations: $\mathrm{br}=$ branchia; nuo $=$ nuchal organ; pal $=$ paleae; $\operatorname{pros}(\mathrm{ml})=$ prostomium (median lobe). Scale bars $=200 \mu \mathrm{m}$. 
5A, 7C-D). Glandular pads above pinnules not observed in intermediate or abdominal uncinigers. Abdominal uncini of AU1-2 similar to thoracic ones (Fig. 3B-D); following ones of typical abdominal shape, with about eight teeth in two vertical rows above rostrum (Fig. 6).

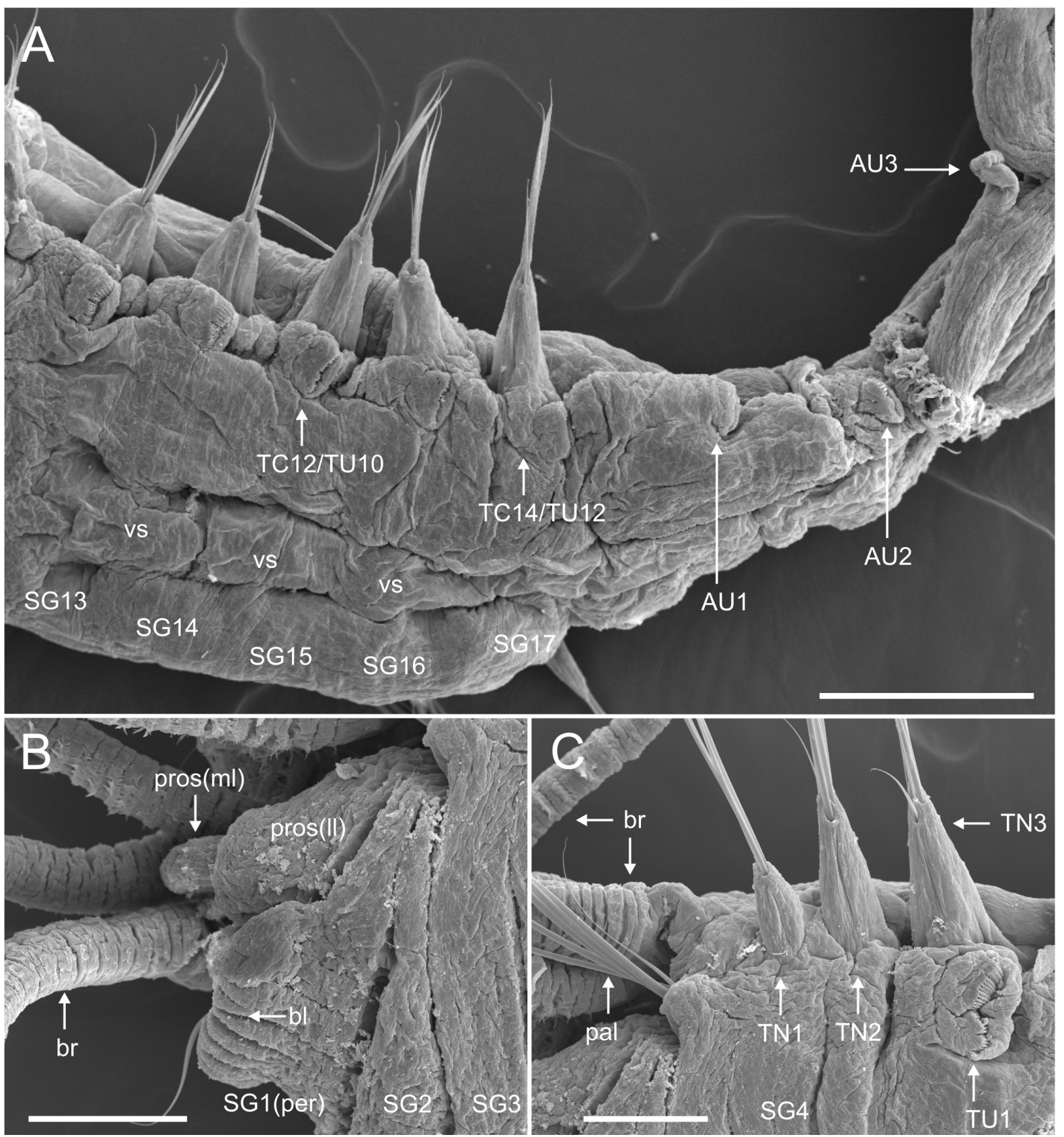

Fig. 5. Ampharete oculicirrata sp. nov., paratype MNCN 16.01/18482_spec. 3. A. Transitional area between thorax and abdomen, ventral view. B. Peristomium, ventral view. C. Paleae and first three thoracic chaetigers, ventral view. Abbreviations: $\mathrm{AU}=$ abdominal unciniger; $\mathrm{bl}=$ buccal lip; $\mathrm{br}=$ branchia; pal $=$ paleae; per $=$ peristomium; $\operatorname{pros}(11)=$ prostomium $($ lateral lobe $) ; \operatorname{pros}(\mathrm{ml})=$ prostomium (median lobe); $\mathrm{SG}=$ segment; $\mathrm{TC}=$ thoracic chaetiger; $\mathrm{TN}=$ thoracic notopodium; $\mathrm{TU}=$ thoracic unciniger; vs $=$ ventral shield. Scale bars: $\mathrm{A}=200 \mu \mathrm{m} ; \mathrm{B}-\mathrm{C}=100 \mu \mathrm{m}$. 
Pygidium. Crenulated due to the presence of low pygidial papillae; with a pair of long lateral cirri (Figs 1D, F, 3F, 7D), each with a pygidial eye located in the proximal third of the cirrus; eyes consisting of two dark pigmented spots (Fig. 1D, F). Fixed specimens creamy white in colour.

StAINING. Head (prostomial tip especially) and ventral thoracic shields dyed by methyl blue.

TuBe. Unknown.

\section{Variations}

Complete specimens measure $4.0-10.0 \mathrm{~mm}$ in length and $0.5-1.0 \mathrm{~mm}$ in width, although most complete specimens are about 4.0-5.0 mm long. One specimen (MNCN 16.01/18482) observed with the ventral pharyngeal organ protruded (Fig. 7A). The buccal lip may appear smooth or rough depending on the state of contraction of the buccal opening (Figs 5B vs 7A). The gap between groups of branchiae is difficult to see in many specimens, but it is obvious in the holotype (Fig. 1C) and several paratypes. Some paratypes have pygidial eyes consisting only of a single pigmented spot (Fig. 1F). Two females (MNCN 16.01/18475, $7 \mathrm{~mm}$ long and MNCN 16.01/18481, $10 \mathrm{~mm}$ long) bear oocytes in the coelomic cavity.

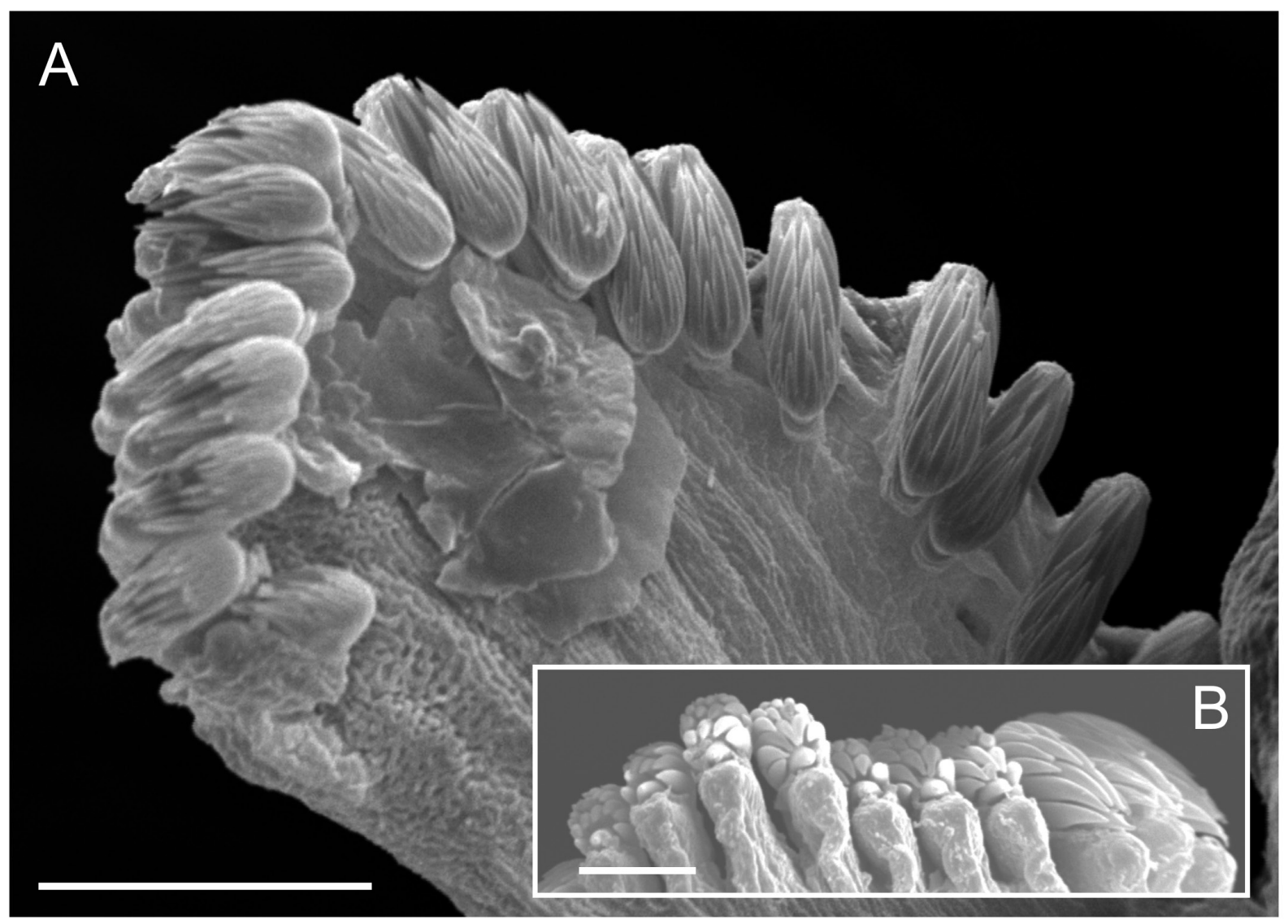

Fig. 6. Ampharete oculicirrata sp. nov., paratype MNCN 16.01/18482_spec. 3. A. Abdominal unciniger 7, posterior view. B. Detail of abdominal uncini, frontal and lateral view. Scale bars: $\mathrm{A}=150 \mu \mathrm{m} ; \mathrm{B}=5 \mu \mathrm{m}$. 
Parapar J. et al., A new species of Ampharete from the NE Atlantic

\section{Distribution and ecology}

Ampharete oculicirrata sp. nov. was found in many localities on the West Shetland shelf in offshore sand and gravel habitats at depths of between 113 and $138 \mathrm{~m}$ (see also Table 1).

\section{Key to North Atlantic species of Ampharete}

Two keys are presented below as an update to those proposed by Parapar et al. (2012) for the North Atlantic species of Ampharete sensu Jirkov (2001) and Imajima et al. (2012). The keys now consider the two morphotypes of A. lindstroemi sensu Holthe (1986) and sensu Parapar et al. (2012), and include species described recently, namely A. undecima Alvestad, Kongsrud \& Kongshavn, 2014; A. santillani Parapar, Kongsrud, Kongshavn, Alvestad, Aneiros \& Moreira, 2018 as well as the new species described herein, Ampharete oculicirrata sp. nov. Both keys complement each other and reflect the traditional (Key 1) and a more recent way of constructing Ampharete keys (Key 2). Thus, Key 1 (following Day 1967;
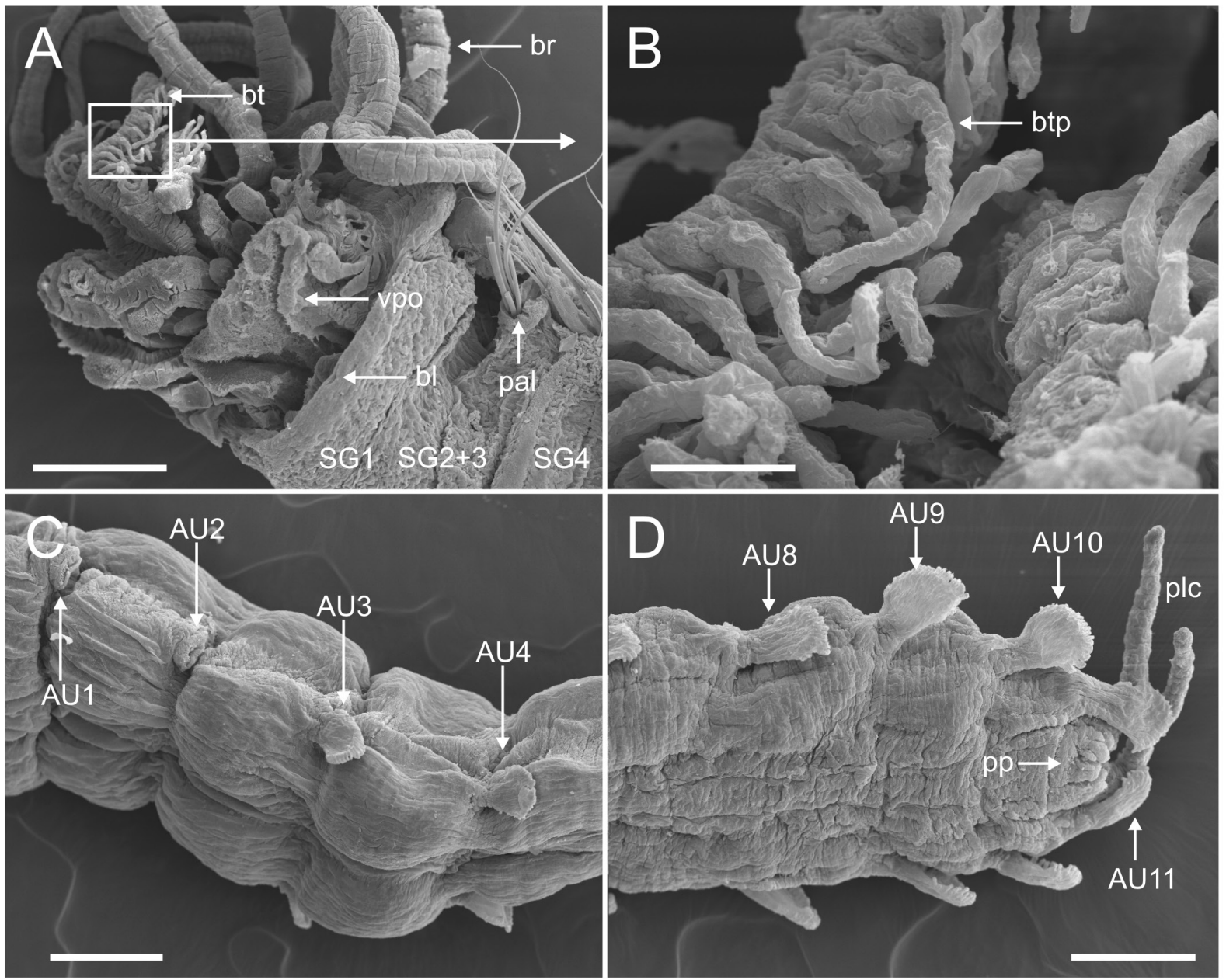

Fig. 7. Ampharete oculicirrata sp. nov., paratype MNCN 16.01/18482_spec. 5. A. Anterior end, ventral view. B. Buccal tentacle with pinnae. C. First four abdominal uncinigers, lateroventral view. D. Posterior end, from AU8 to pygidium, ventral view. Abbreviations: AU = abdominal unciniger; $b l=$ buccal lip; br = branchia; $b t=$ buccal tentacle; btp = buccal tentacle pinna; pal $=$ paleae; $p l c=$ pygidial lateral cirrus; $p p=$ pygidial papillae $; \mathrm{SG}=$ segment $; \mathrm{vpo}=$ ventral pharyngeal organ. Scale bars: A, C $=150 \mu \mathrm{m} ; \mathrm{B}=25 \mu \mathrm{m} ; \mathrm{D}=100 \mu \mathrm{m}$. 
Holthe 1986; Hartmann-Schröder 1996) relies on meristic characters such as the number of thoracic and abdominal uncinigers, the number of papillae in pygidium and the length of paleae; whereas Key 2, (following Jirkov 2001; Jirkov \& Leontovich 2013) emphasises other features, such as the shape of paleae, the shape of the rudimental notopodia of first two anterior abdominal uncinigers, and branchial arrangement. A synoptic table, summarising the diagnostic characters of all NE Atlantic species known prior to the new species described herein, is given in Parapar et al. (2018).

\section{Key 1}

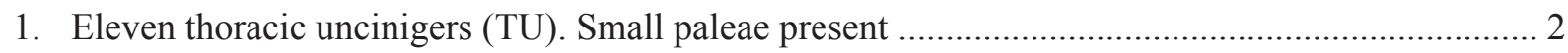

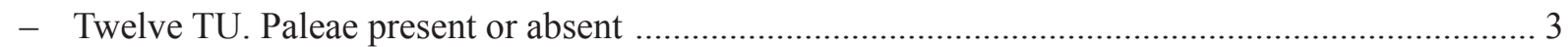

2. Twelve abdominal uncinigers (AU) ………………............................... borealis (M. Sars, 1856)

- Fifteen to eighteen AU ……………………………......................... octocirrata (M. Sars, 1835)

3. Paleae absent ........................................................................................ petersenae Jirkov, 1997

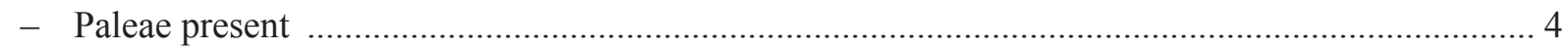

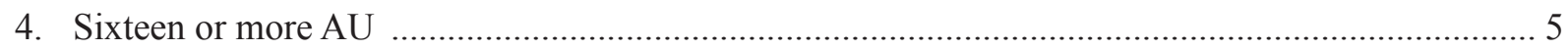

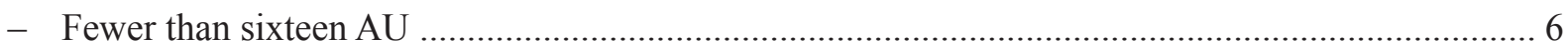

5. Sixteen to eighteen AU ........................................................................... goesi (Malmgren, 1866)

- Twenty-four to twenty-eight AU ....................................................................... vega (Wirén, 1883)

6. Thirteen $\mathrm{AU}$.................................................................................. finmarchica (M. Sars, 1865)

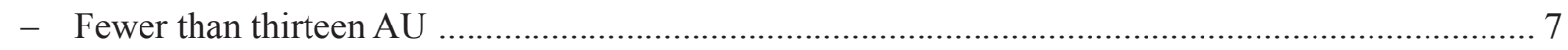

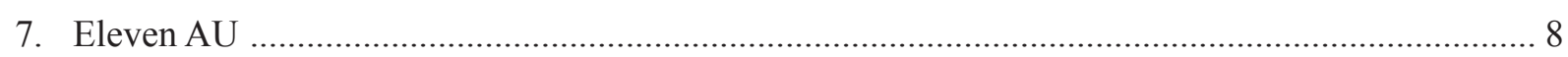

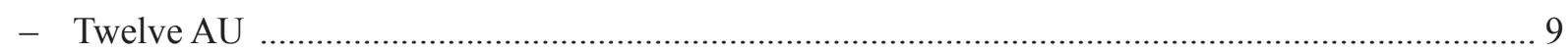

8. Pygidium with two long cirri and several small, low papillae. Prostomium and pygidial cirri with eyes Ampharete oculicirrata sp. nov.

- Pygidium with two short lateral cirri and several small, rounded papillae. No prostomial or pygidial eyes ............................................................. A. undecima Alvestad, Kongsrud \& Kongshavn, 2014

9. Paleae shorter than distance between the two groups of branchiae ............. A. falcata Eliason, 1955

- Paleae longer than distance between the two groups of branchiae ............................................... 10

10. Paleae stout and gradually but quickly tapering terminally

A. villenai Parapar, Helgason, Jirkov \& Moreira, 2012

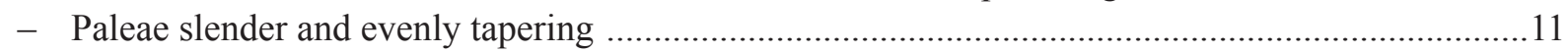

11. Abdominal neuropodia with long dorsal cirrus .................................... A. acutifrons (Grube, 1860)

- Abdominal neuropodia with short dorsal cirrus ...................................................................... 12

12. Pygidium with two long cirri and several long papillae ............................... baltica Eliason, 1955

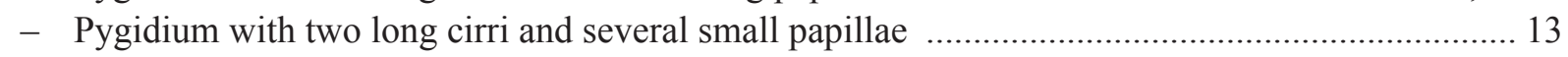

13. Paleae long, widely surpassing the prostomium

A. lindstroemi Malmgren in Hessle, 1917 sensu Parapar et al. (2012)

- Paleae short, not surpassing the prostomium 
14. Pygidial cirri with eyes; without dorsal neuropodial cirrus in posterior abdominal segments A. lindstroemi Malmgren in Hessle, 1917 sensu Holthe (1986)

- Pygidial cirri without eyes; with a short dorsal neuropodial cirrus in posterior abdominal segments

A. santillani Parapar et al., 2018

\section{Key 2}

1. Paleae stout

- Paleae absent or if present, slender and evenly tapering to long filiform tips

2. Paleae gradually but quickly tapering to comparatively long filiform tips (rarely missing) .................................................... A. villenai Parapar, Helgason, Jirkov \& Moreira, 2012

- Paleae abruptly tapering to very short filiform tips (usually missing)

3. Thirteen abdominal uncinigers (AU)

A. finmarchica (M. Sars, 1865)

- Sixteen to eighteen AU A. goesi (Malmgren, 1866)

4. Rudimental notopodia of first two AU enlarged 5

- All rudimental notopodia of similar size 6

5. Gap between branchial groups as wide as width of group, $12 \mathrm{AU}$

- Gap between branchial groups narrow or absent. 24-28 AU A. vega (Wirén, 1883)

6. Paleae at least twice as long or wide as the most developed notochaetae

- Paleae delicate, only slightly longer than the following notochaetae or absent

7. AU with long cirrus A. acutifrons (Grube, 1860)

- AU cirrus (if present) short

8. Pygidium with two long cirri and several short papillae

- Pygidium with two long cirri and several long papillae A. baltica Eliason, 1955

9. Pygidial cirri with a pair of eyes ..... A. lindstroemi Malmgren in Hessle, 1917 sensu Holthe (1986)

- Pygidial cirri without eyes

10. Paleae short and stout, not surpassing anterior margin of prostomium

A. santillani Parapar et al., 2018

- Paleae long and slender, clearly surpassing prostomium

A. lindstroemi Malmgren in Hessle, 1917 sensu Parapar et al. (2012)

11. Paleae absent; 12 thoracic uncinigers (TU) A. petersenae Jirkov, 1997

- Paleae delicate, only slightly longer than the following notochaetae

12. Eleven TU

- Twelve TU

13. Prostomium and pygidial cirri with eyes

Ampharete oculicirrata sp. nov.

- No prostomial or pygidial eyes A. undecima Alvestad, Kongsrud \& Kongshavn, 2014

14. Three branchiae in each group arranged in line and fourth branchia posterior to this row

- All four branchiae in each group arranged in line A. octocirrata (M. Sars, 1835) 


\section{Discussion}

Imajima et al. (2012) provide some observations on morphological relevant characters for the taxonomy of Ampharetidae, including the shape of the parapodia, the insertion of the branchiae, notopodial rudiments of ventral shields, and uncinal dentition. The constant presence of two intermediate segments in the genus Ampharete is here endorsed.

The morphological characters of $A$. oculicirrata sp. nov. suggest that this species might fit within the clade constituted by A. santillani / A. lindstroemi / A. undecima as presented by Parapar et al. (2018). Thus, according to Table 1 in Parapar et al. (2018), the most relevant feature of Ampharete oculicirrata sp. nov. is the possession of only 11 abdominal segments; this character is only shared with A. undecima from the Norwegian Sea (Alvestad et al. 2014). Furthermore, both species have a small body size and delicate paleae, which are only slightly longer than the thoracic notochaetae, and prostomial tip strongly dyed with methyl blue. However, A. oculicirrata sp. nov. differs from A. undecima according to the following characters: 1) buccal tentacle papillae (pinnae) are much longer and organized in two rows in A. oculicirrata sp. nov. (longer than the tentacle diameter) (Fig. 7B), while in A. undecima papillae are short, numerous and organized in several rows (see Alvestad et al. 2014; Fig. 4B-C); this character is only visible under the SEM and deserves further investigation in other species of Ampharete; 2) A. oculicirrata sp. nov. bears branchiae that are much longer, reaching to the middle of the thorax (TU5-6), while in A. undecima they only reach to TU1-2;3) presence of a short gap between the two branchial groups in A. oculicirrata sp. nov., while there is no such gap in A. undecima; 4) A. oculicirrata sp. nov. bears prostomial and pygidial eyes, while eyes are lacking in A. undecima; 5) A. oculicirrata sp. nov. bears a pygidium provided with a crenulated anal edge due to the presence of low papillae, and a pair of long lateral cirri, while A. undecima has several spherical papillae and a pair of short cirri. In addition, both species bear anterior thoracic uncini that show a similar number of teeth above rostrum; however, teeth are organised in two well defined vertical rows in A. oculicirrata sp. nov. (TU2 in Fig. 2E) while such rows are not clearly distinguished in A. undecima (see Fig. 5C in Alvestad et al. 2014.). Finally, A. undecima is so far only known from slope depths (600-1650 m), while A. oculicirrata sp. nov. is present on the shelf at $113-138 \mathrm{~m}$ depth.

On the other hand, A. lindstroemi Malmgren in Hessle, 1917, as described by Holthe (1986) is also close to A. oculicirrata sp. nov. This taxon, which probably represents a species complex (Parapar et al. 2018) shares with the new species the following characteristics: 1) paleae that are delicate and gradually tapering to a long filiform tip; 2) the presence of prostomial and pygidial eyes; and 3) a pygidium provided with a pair of long lateral cirri. Nevertheless, A. lindstroemi is clearly distinguished by having 12 AU instead of 11.

Finally, A. santillani shares with A. oculicirrata sp. nov. the presence of prostomial eyes, a short branchial gap (though much wider than that of $A$. oculicirrata sp. nov.) and a similar pygidium (although with lateral cirri notably shorter); nevertheless, it differs from A. oculicirrata sp. nov. in the following: 1) A. santillani is a larger species $(11-22 \mathrm{~mm}$ in length vs $4-10 \mathrm{~mm}) ; 2)$ the paleae are more numerous and notably thicker in A. santillani; 3 ) the number of AU (12-13 in A. santillani vs 11 in A. oculicirrata sp. nov.); and 4) the presence of a neuropodial dorsal cirrus in abdominal uncinigers in A. santillani, which are absent in A. oculicirrata sp. nov.

\section{Acknowledgements}

Our special thanks go to JNCC and MSS for making this material available for study. The authors would like to thank the master and crew of M.R.V. Scotia. This work was undertaken by the Joint Nature Conservation Committee and Marine Scotland Science and part funded by Scottish Government project SP02Q. We also would like to thank Daisy Chamberlain and the marine team at Thomson Unicomarine 
for their help in processing the samples. Furthermore, Ada Castro and Catalina Sueiro (Servizos de Apoio á Investigación - SAI, Universidade da Coruña, Spain) are thanked for assisting with the preparation of the specimens and the use of the SEM, and Miguel Ángel Alonso-Zarazaga (Museo Nacional de Ciencias Naturales, Madrid) for etymological advice. This study was partly supported by the research project 'Fauna Ibérica: Polychaeta VI. Palpata. Canalipalpata I' (CGL2014-53332-C5-3-P). We thank two anonymous referees for their critical and constructive suggestions, which greatly improved the quality of the final version of the manuscript.

\section{References}

Alvestad T., Kongsrud J.A. \& Kongshavn K. 2014. Ampharete undecima, a new deep-sea ampharetid (Annelida, Polychaeta) from the Norwegian Sea. Memoirs of Museum Victoria 71: 11-19. https://doi.org/10.24199/j.mmv.2014.71.02

Day J.H. 1967. A monograph on the Polychaeta of Southern Africa. Part 2. Sedentaria. Trustees of the British Museum (Natural History), London. https://doi.org/10.1017/S0025315400019299

Hartmann-Schröder G. 1996. Annelida. Borstenwürmer. Polychaeta. Die Tierwelt Deutschlands 58, $2^{\text {nd }}$ ed. Gustav Fischer, Jena.

Holthe T. 1986. Polychaeta Terebellomorpha. Marine Invertebrates of Scandinavia 7: 1-192.

Imajima M., Reuscher M.G. \& Fiege D. 2012. Ampharetidae (Annelida: Polychaeta) from Japan. Part I: The genus Ampharete Malmgren. 1866, along with a discussion of several taxonomic characters of the family and the introduction of a new identification tool. Zootaxa 3490: 75-88.

http://doi.org/10.11646/zootaxa.3490.1.6

Jirkov I. 1994. Two new species of Ampharete (Polychaeta: Ampharetidae) from the North-Western Pacific with discussion of paleae as taxonomic character of Ampharetinae. Zoologicheskii Zhurnal 73 (4): 28-32.

Jirkov I. 1997. Ampharete petersenae Jirkov, sp. n. (Ampharetidae. Polychaeta) from the Northern Atlantic. Zoologicheskii Zhurnal 76: 1418-1420. [in Russian.]

Jirkov I.A. 2001. [Polychaeta of the Arctic Ocean]. Yanus-K. Moskva. [in Russian.]

Jirkov I. 2011. Discussion of taxonomic characters and classification of Ampharetidae (Polychaeta). Italian Journal of Zoology 78 (Suppl.): 78-94. https://doi.org/10.1080/11250003.2011.617216

Jirkov I.A. \& Leontovich M.K. 2013. Identification keys for Terebellomorpha (Polychaeta) of the Eastern Atlantic and the North Polar Basin. Invertebrate Zoology 10: 217-243.

https://doi.org/10.15298/invertzool.10.2.02

Lamarck J.B.P.A. de 1838. Les Annélides (Annelides). Classe neuvième. In Lamarck, J.B.P.A. de (ed.). Histoire naturelle des animaux sans vertèbres, présentant les caractères généraux et particuliers de ces animaux, leur distribution, leurs classes, leurs familles, leurs genres, et la citation des principales espèces qui s'y rapportent; précédée d'une introduction offrant la détermination des caractères essentiels de l'animal, sa distinction du végétal et des autres corps naturels, enfin, l'exposition des principes fondamentaux de la zoologie: 499-639. Tome 5, 2 édition. J.B. Baillière, Paris. https://doi.org/10.5962/bhl.title.63986

Nygren A., Parapar J., Pons J., Meißner K., Bakken T., Kongsrud J.A., Oug E., Gaeva D., Sikorski A., Johansen R.A., Hutchings P.A., Lavesque N. \& Capa M. 2018. A mega-cryptic species complex hidden among one of the most common annelids in the North East Atlantic. PLoS ONE 13 (6): e0198356. https://doi.org/10.1371/journal.pone.0198356 
Parapar J., Helgason G.V., Jirkov I. \& Moreira J. 2012. Polychaetes of the genus Ampharete (Polychaeta: Ampharetidae) collected in Icelandic waters during the BIOICE project. Helgoland Marine Research 66: 331-344. https://doi.org/10.1007/s10152-011-0274-z

Parapar J., Kongsrud J.A., Kongshavn K., Alvestad T., Aneiros. F. \& Moreira J. 2018. A new species of Ampharete (Annelida: Ampharetidae) from the NW Iberian Peninsula, with a synoptic table comparing NE Atlantic species of the genus. Zoological Journal of the Linnean Society 183: 526-555.

https://doi.org/10.1093/zoolinnean/zlx077

Taylor J., O'Connor J., Golding N., Last E., Drewery J. \& Boulcott P. (In press). 1517S Cruise Report: Monitoring survey of North-east Faroe Shetland Channel NCMPA, Wyville-Thomson Ridge SAC \& West Shetland Shelf NCMPA. JNCC Report No. Series. JNCC, Peterborough.

Manuscript received: 19 January 2019

Manuscript accepted: 26 March 2019

Published on: 13 June 2019

Topic editor: Rudy Jocqué

Desk editor: Marianne Salaün

Printed versions of all papers are also deposited in the libraries of the institutes that are members of the EJT consortium: Muséum national d'Histoire naturelle, Paris, France; Botanic Garden Meise, Belgium; Royal Museum for Central Africa, Tervuren, Belgium; Royal Belgian Institute of Natural Sciences, Brussels, Belgium; Natural History Museum of Denmark, Copenhagen, Denmark; Naturalis Biodiversity Center, Leiden, the Netherlands; Museo Nacional de Ciencias Naturales-CSIC, Madrid, Spain; Real Jardín Botánico de Madrid CSIC, Spain; Zoological Research Museum Alexander Koenig, Bonn, Germany; National Museum, Prague, Czech Republic. 